\title{
Clinical picture: multiple sites of ectopic pancreatic tissue
}

\author{
J Straatman ${ }^{1 *}$, R J Meester ${ }^{1}$, N C T v. Grieken², M J A M Jacobs ${ }^{3}$, P d. Graaf ${ }^{4}$, G Kazemier $^{1}$ and M A Cuesta ${ }^{1}$
}

\begin{abstract}
A case is presented with multiple sites of ectopic pancreatic tissue in the gastro-intestinal tract. The sites were found in the stomach and duodenum, one site of ectopic pancreatic tissue presented with necrotizing pancreatitis. Ectopic pancreatic tissue can be defined as all pancreatic tissue, with no anatomical or vascular continuity with the orthotopic pancreas. The ectopic tissue most likely originates from the spreading of cells, during the allocation of structures derived from the foregut in the embryonic phase. Over ninety percent of ectopic tissue presents in the upper gastrointestinal tract, although other locations have been described. To date this is the first case-report about a patient with multiple localizations of ectopic pancreatic tissue.
\end{abstract}

\section{Background}

Pancreatic tissue, with no anatomical or vascular continuity with the orthotopic pancreas, is described as aberrant pancreas or ectopic pancreatic tissue. The prevalence of ectopic pancreatic tissue is reported to be around $0.25 \%$ in the general population, whereas a prevalence of around $14 \%$ is reported in autopsy material (Dolan et al. 1974; Tanaka et al. 1993). The presence of ectopic pancreatic tissue is usually asymptomatic.

Ectopic pancreatic tissue is most often reported in the stomach, duodenum and jejunum, yet many other locations have been reported (Wlaz et al. 2014). Multiple case reports depict different presentations of ectopic pancreatic tissue, describing only singular sites. To our knowledge this is the first case of ectopic pancreatic tissue presenting at multiple sites.

\section{Case-report}

A 61-year-old woman presented to the outpatient clinic of the VU University Medical Center (VUmc), Amsterdam, the Netherlands, with complaints of dysphagia. Computer tomography (CT) scan and magnetic resonance imaging (MRI) of the neck and chest depicted a right dorsolateral para-esophageal mass near the upper

\footnotetext{
*Correspondence: Je.straatman@vumc.nl

1 Department of Surgery, VU University Medical Center,

Amsterdam, The Netherlands

Full list of author information is available at the end of the article
}

esophageal sphincter. Dimensions were $13 \mathrm{~mm}$ axially and $35 \mathrm{~mm}$ cranio-caudally. The mass was confirmed on endoscopic ultrasound and seemed to be expanding from the muscularis propria. Based on these findings the mass was suspected to be a leiomyoma.

The patient underwent surgical exploration of the neck, searching for suspected leiomyoma of the cervical esophagus. During surgery the tumor could not be identified, even with peri-operative endoscopic ultrasound.

Although no tumor was identified during surgery, the patient presented with progressing complaints of dysphagia. Multiple gastroscopies were performed with dilation of the esophagus, with good effects on the patient's complaints.

Follow-up endoscopy was performed 1 year later. During the examination a small mass with a central opening was visible in the antrum of the stomach. These findings are consistent with ectopic pancreatic tissue with an accessory pancreatic duct. Biopsies were performed, but quality of the biopsies was too poor to determine the diagnosis. The mass was monitored with bi-annual endoscopy.

Three years later the patient presented with microcytic anemia. Endoscopy was repeated and showed an ulcerated submucosal tumor in the fundus of the stomach. The previously identified mass in the antrum was still present and unchanged in comparison to the site found 3 years ago (Figure 1).

\section{Springer}

(c) 2015 Straatman et al. This article is distributed under the terms of the Creative Commons Attribution 4.0 International License (http://creativecommons.org/licenses/by/4.0/), which permits unrestricted use, distribution, and reproduction in any medium, provided you give appropriate credit to the original author(s) and the source, provide a link to the Creative Commons license, and indicate if changes were made. 

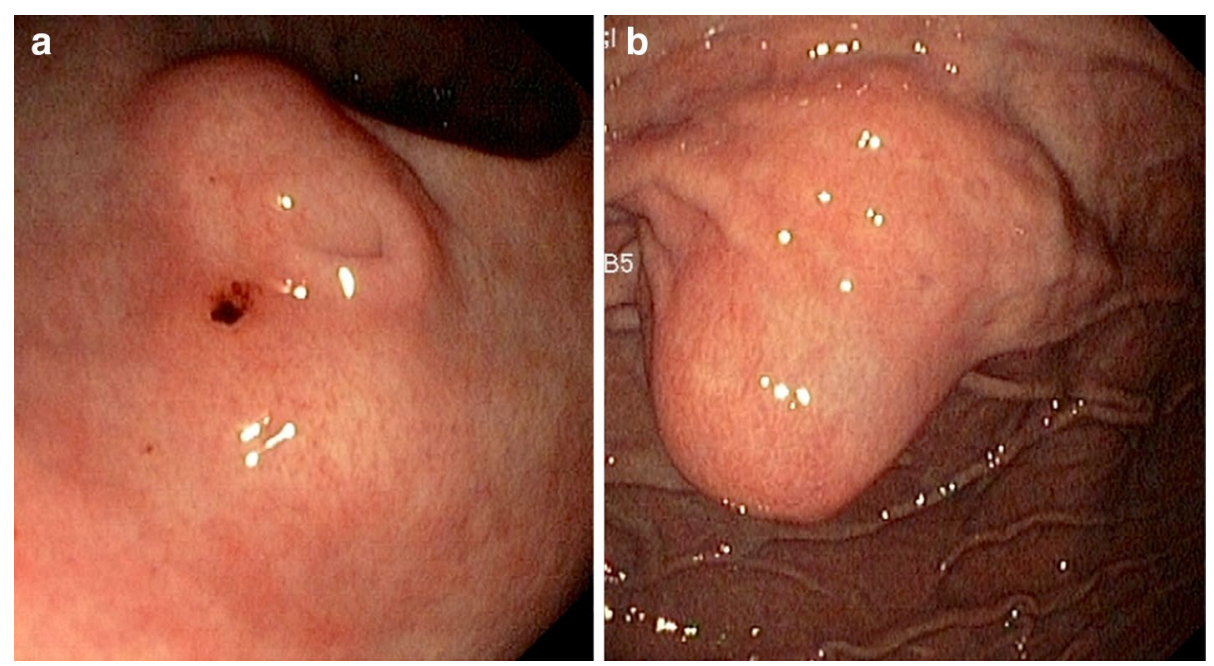

Figure 1 a Aberrant pancreatic tissue of the stomach with duct and $\mathbf{b}$ suspected neuro-endocrine tumour, which was a second site of ectopic pancreatic tissue upon analysis.

Microscopic analysis depicted normal gastric mucosa in the fundus. In the biopsy from the antrum pancreatic tissue was identified. Additional computer tomography (CT)-scan imaging was performed; showing the tumor in the fundus was centrally calcifying. These findings are consistent with a neuro-endocrine tumor and an indication for resection.

A laparoscopic wedge resection of the mass in the fundus was performed. Postoperative recovery was uncomplicated. The pathologist described a mass of ectopic pancreatic tissue with a central duct and acute necrotizing pancreatitis (Figure 2).

Two sited of ectopic pancreatic tissue were now confirmed, one being the aberrant tissue with accessory duct in the antrum of the stomach, the second being the tumor in the fundus with necrotizing pancreatitis.

Following these results, the tumor in the esophagus was studied with MRI under suspicion of a third site of ectopic pancreatic tissue. The MRI image depicted the esophageal mass near the upper esophageal sphincter, compatible with a benign tumor. As the patient had no progression of complaints it was decided that re-exploration of the cervical esophagus was not necessary.

The patient is followed-up bi-annually for assessment of the sites in the esophagus and stomach with endoscopy. The last endoscopy revealed two new sites of ectopic pancreatic tissue, one being in the stomach and another site was observed in the duodenum. As all sites are asymptomatic, resection is not deemed indicated.

\section{Discussion}

The clinical incidence of ectopic pancreatic tissue is rare and believed to be $0.25 \%$ (Tanaka et al. 1993). Whereas rates have been described to be as high as $13.7 \%$ in autopsy material, indicating a high incidence of asymptomatic ectopic pancreatic tissue (Dolan et al. 1974). Symptomatic patients often present with wide range of symptoms, such as abdominal pain, dysphagia and in rare complicated cases patients present with pancreatitis, pseudocysts, upper gastrointestinal bleeding or even adenocarcinoma of ectopic pancreatic tissue (Osanai et al. 2001; Lee et al. 2014).

The ectopic tissue most likely originates from the embryonic phase, spreading of cells during the allocation of the structures originating out of the foregut (Lai and Tompkins 1986). The exact pathology is unknown but theories support wrong positioning of the pancreatic tissue during rotation of the foregut or wrongly distributed neuroendocrine cells (amine precursor uptake decarboxylase cells) in the embryonic phase as origin of the aberrant pancreas (Zinkiewicz et al. 2003).

As described above, the incidence of ectopic pancreatic tissue, without symptoms, is high. Indicating, ectopic pancreatic tissue does not require resection or other treatment if no symptoms are present (Dolan et al. 1974). The ectopic tissue in the antrum of the presented patient is asymptomatic, it was visualized 3 year prior to the resection of the mass in the fundus upon routine endoscopy due to complaints of dysphagia. Symptoms are usually associated with pancreatitis, stenosis or malignancy. 


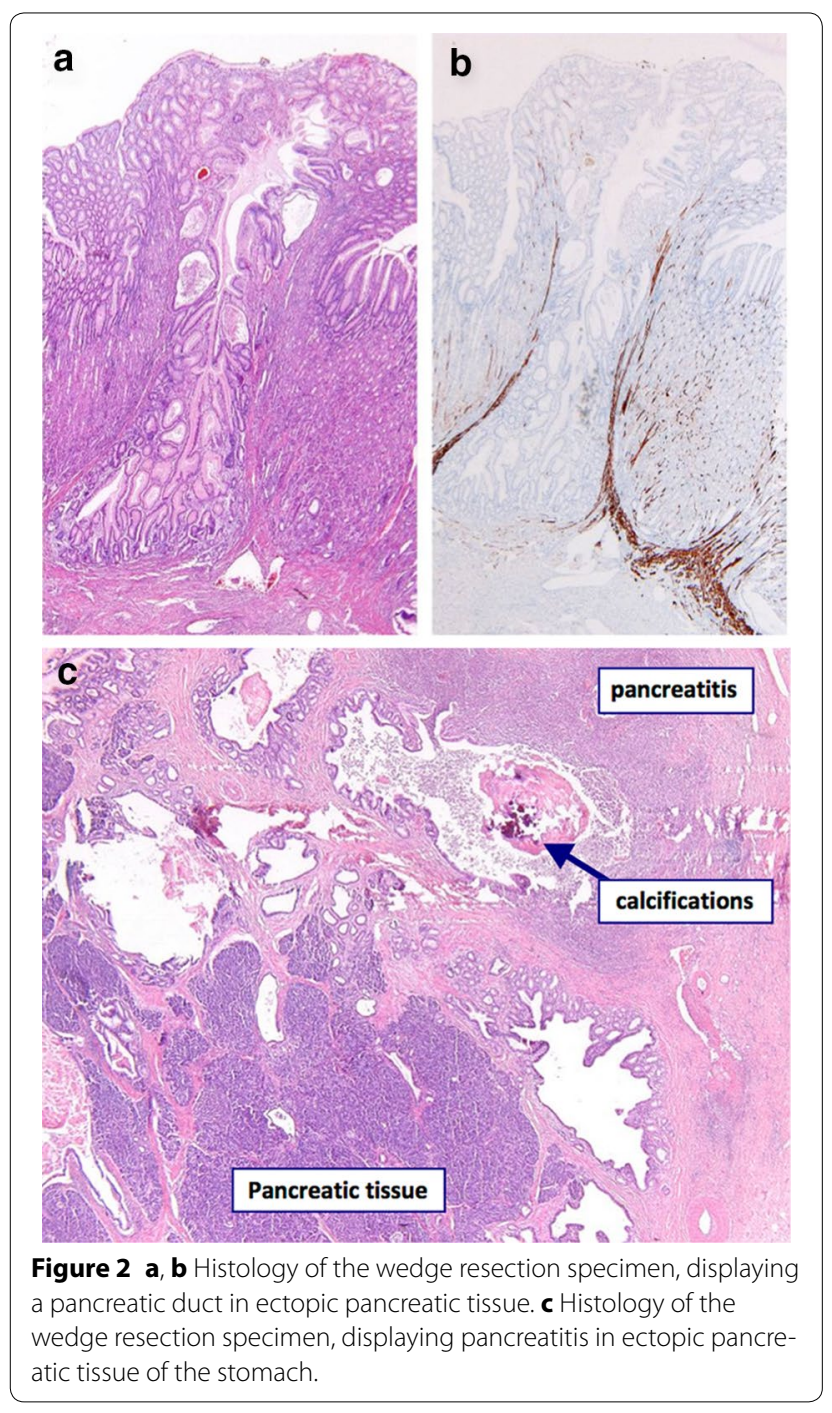

Previous case-reports describe pancreatitis, intussusception, neuro-endocrine tumors, bleeding and obstruction arising from ectopic pancreatic tissue (Razi 1966; Okasha et al. 2013; Habibi et al. 2014; Monier et al. 2014).

With regard to localization $90 \%$ of ectopic pancreatic tissue sites are found in the upper gastrointestinal tract, with $27.5 \%$ of cases arising in the stomach (Wlaz et al. 2014). Sites have also been reported in the esophagus, ileum, colon, mesentery and omentum (Mortele et al. 2006). Ectopic pancreatic tissue of the stomach may be hard to distinguish from mesenchymal tumors such as leiomyoma or gastrointestinal stromal tumors (GIST) (Park et al. 2011). Diagnostic studies should differentiate between premalignant sites and innocent ectopic pancreatic tissue. Ectopic pancreatic tissue may present differently on ultrasound, CT and MRI. Definitive diagnosis may be obtained with histology following fine-needle aspiration or resection (Attwell et al. 2015).

\section{Conclusion}

Previous case-reports describe singular sites of ectopic pancreatic tissue, to our knowledge this is the first reported case of a patient presenting with multiple sites of symptomatic ectopic pancreatic tissue (Carvalho et al. 2014; Filip et al. 2014; Macedo et al. 2014).

\section{Authors' contributions}

MAC and GK designed the manuscript and operated the patient. JS and RJM collected data and drafted the manuscript. MJAMJ and PdG re-evaluated all radiological studies. NCTvG re-evaluated all pathological specimens. All authors read and approved the final manuscript.

\section{Author details}

1 Department of Surgery, VU University Medical Center, Amsterdam, The Netherlands. ${ }^{2}$ Department of Pathology, VU University Medical Center, Amsterdam, The Netherlands. ${ }^{3}$ Department of Gastroenterology, VU University Medical Center, Amsterdam, The Netherlands. ${ }^{4}$ Department of Radiology, VU University Medical Center, Amsterdam, The Netherlands.

\section{Compliance with ethical guidelines}

\section{Competing interests}

The authors declare that they have no competing interests.

\section{Consent for publication}

This case-report was published with the patient's consent.

Received: 17 February 2015 Accepted: 28 May 2015

Published online: 26 June 2015

\section{References}

Attwell A, Sams S, Fukami N (2015) Diagnosis of ectopic pancreas by endoscopic ultrasound with fine-needle aspiration. World I Gastroenterol 21(8):2367-2373

Carvalho R, Freire P, Portela F, Gomes D, Andrade P, Bento A et al (2014) Ectopic pancreas as a rare cause of obstructive jaundice. Rev Esp Enferm Dig 106(8):557-558

Dolan RV, ReMine WH, Dockerty MB (1974) The fate of heterotopic pancreatic tissue. A study of 212 cases. Arch Surg 109(6):762-765

Filip R, Walczak E, Huk J, Radzki RP, Bienko M (2014) Heterotopic pancreatic tissue in the gastric cardia: a case report and literature review. World $\mathrm{J}$ Gastroenterol 20(44):16779-16781

Habibi H, Devuni D, Rossi L (2014) Ectopic pancreas: a rare cause of abdominal pain. Conn Med 78(8):479-480

Lai EC, Tompkins RK (1986) Heterotopic pancreas. Review of a 26 year experience. Am J Surg 151(6):697-700

Macedo Fl, Taggarshe D, Makarawo T, Herschman B, Jacobs MJ (2014) Pancreatic intraepithelial neoplasia arising from an ectopic pancreas in the small bowel. Hepatobiliary Pancreat Dis Int 13(6):658-661

Monier A, Awad A, Szmigielski W, Muneer M, Alrashid A, Darweesh A et al (2014) Heterotopic pancreas: a rare cause of ileo-ileal intussusception. Pol J Radiol 79:349-351

Mortele KJ, Rocha TC, Streeter JL, Taylor AJ (2006) Multimodality imaging of pancreatic and biliary congenital anomalies. Radiographics 26(3):715-731

Okasha HH, Al-Bassiouni F, El-Ela MA, Al-Gemeie EH, Ezzat R (2013) A retroperitoneal neuroendocrine tumor in ectopic pancreatic tissue. Endosc Ultrasound 2(3):168-170

Osanai M, Miyokawa N, Tamaki T, Yonekawa M, Kawamura A, Sawada N (2001) Adenocarcinoma arising in gastric heterotopic pancreas: clinicopathological and immunohistochemical study with genetic analysis of a case. Pathol Int 51(7):549-554

Park SH, Kim GH, Park do Y, Shin NR, Cheong JH, Moon JY et al (2011) Endosonographic findings of gastric ectopic pancreas: a single center experience. J Gastroenterol Hepatol 26(9):1441-1446 
Razi MD (1966) Ectopic pancreatic tissue of esophagus with massive upper gastrointestinal bleeding. Arch Surg 92(1):101-104

Tanaka K, Tsunoda T, Eto T, Yamada M, Tajima Y, Shimogama H et al (1993) Diagnosis and management of heterotopic pancreas. Int Surg 78(1):32-35

Wlaz J, Madro A, Kazmierak W, Celinski K, Slomka M (2014) Pancreatic and gastric heterotopy in the gastrointestinal tract. Postepy Hig Med Dosw (Online) 68:1069-1075
Lee SJ, Kim GH, Park do Y, Choi SA, Lee SH, Choi YY et al (2014) Acute ectopic pancreatitis occurring after endoscopic biopsy in a gastric ectopic pancreas. Clin Endosc 47(5):455-459

Zinkiewicz K, Juskiewicz W, Zgodzinski W, Szumilo J, Cwik G, Furtak J et al (2003) Ectopic pancreas: endoscopic, ultrasound and radiological features. Folia Morphol (Warsz) 62(3):205-209

\section{Submit your manuscript to a SpringerOpen ${ }^{\odot}$} journal and benefit from:

- Convenient online submission

- Rigorous peer review

- Immediate publication on acceptance

- Open access: articles freely available online

- High visibility within the field

- Retaining the copyright to your article

Submit your next manuscript at $\gg$ springeropen.com 